\title{
Reaction of Exotic Soybean Germplasm to Phakopsora pachyrhizi in Uganda
}

\author{
H. K. Oloka and P. Tukamuhabwa, Department of Crop Science, Makerere University, P.O. Box 7062 Kampala, \\ Uganda; T. Sengooba, Program for Biosafety Systems, IFPRI-Uganda, P. O. Box 28565, Kampala, Uganda; and \\ S. Shanmugasundram, AVRDC, P.O. Box 42, Shanhua, Tainan 74199, Taiwan
}

\begin{abstract}
Oloka, H. K., Tukamuhabwa, P., Sengooba, T., and Shanmugasundram, S. 2008. Reaction of exotic soybean germplasm to Phakopsora pachyrhizi in Uganda. Plant Dis. 92:1493-1496.

Host plant resistance is the best long-term strategy for managing soybean rust (Phakopsora pachyrhizi) in endemic areas. Resistance breeding efforts are hampered by the presence of several races of the pathogen that often overcome single resistance genes deployed against them. In Uganda, only two soybean cultivars show moderate resistance to Phakopsora pachyrhizi, but this is likely to break down given the aggressive nature of the pathogen. A total of 25 rust tolerant or resistant accessions were imported from the Asian Vegetable Research and Development Centre and screened at Namulonge, in central Uganda. Only 10 accessions, G 33, G 8527, G8586, G 8587, GC 60020-8-7-7-18, GC 87016-11-B-2, GC 87021-26-B-1, SRE-D-14A, SRE-D-14B, and SS 86045-23-2, showed no rust symptoms at growth stage R6 during the three seasons of testing. Soybean rust resistance genes Rpp1, Rpp3, and Rpp4 did not confer resistance at Namulonge; gene Rpp2 was effective.
\end{abstract}

Worldwide soybean production is threatened by Asian soybean rust, a disease previously restricted to East Asia and Australia $(5,20,21)$. Soybean rust is incited by the fungus Phakopsora pachyrhizi Sydow, a highly variable and aggressive pathogen known to infect several species in the leguminaceae (24). In the past 10 years, the pathogen has spread to Africa, South America, and very recently into North America $(5,17,22,23,28,29)$. High yield losses (10 to $90 \%$ ) have been observed in many countries, as nearly all cultivars grown in new locales of the disease have been susceptible $(2,3,12)$. In Uganda, soybean rust was first reported in 1996 at a research station in Namulonge, central Uganda (28). The disease was later observed in many farmers' fields throughout the country, where it infected all commercial soybean cultivars at the time. Yield losses in these ranged between 10 and 33\% in cultivars Nam 1 and Nam II, depending on season and location (11).

A variety of management options have been proposed for soybean rust (1). Common control measures include chemical control using systemic and protectant fungicides and host plant resistance $(11,13,16,19)$. Fungicides have been effective in Zimbabwe, South Africa, the United States, Brazil, and Argentina. In Uganda, a variety of fungicides are effective against

Corresponding author: Oloka Herbert Kefa

E-mail: olokahk@agric.mak.ac.ug

Accepted for publication 1 July 2008.

doi:10.1094/PDIS-92-11-1493

(C) 2008 The American Phytopathological Society soybean rust $(12,27)$, but their use has been limited due to high costs for product and application. In addition, fungicides raise concerns about pollution, phytotoxicity, toxicity to humans and livestock, and nontarget effects (5). Host plant resistance would provide a cheaper, environmentally friendly, and sustainable approach for managing soybean rust under resource poor agricultural systems that characterize the agricultural landscape of Uganda.

Resistance mechanisms identified against $P$. pachyrhizi include specific resistance, partial resistance, and tolerance (7). Four specific resistance genes (Rppl, $R p p 2$, Rpp3, Rpp4) have been identified in soybeans (9). Use of these genes for development of rust-resistant soybean cultivars has been complicated by the high variability within $P$. pachyrhizi. Soon after deployment, single resistance genes are known to succumb to certain isolates of the pathogen (8). For instance, Hartwig (9) reported that the resistance gene Rppl, in cultivar Komata from Japan, produced a susceptible reaction on isolates TW 72-1 and TW 80-2 from Taiwan. Single-gene resistance is not durable and is largely useless (7).

In Uganda, two moderately resistant cultivars (Maksoy $1 \mathrm{~N}$ and Namsoy $4 \mathrm{M}$ ) are currently being used in the management of soybean rust (26), but under severe rust pressure, these cultivars develop rust which may result in yield losses. These cultivars contain specific resistance genes to soybean rust (14) that are likely to break down as $P$. pachyrhizi races proliferate in the country. In view of this, there is need to broaden the germplasm base for soybean rust resistance breeding using genetic material from many possible sources. This study examined 25 soybean accessions previously selected for resistance or tolerance to soybean rust at the Asian Vegetable Research and Development Centre (AVRDC). The objective of this study was to assess the effectiveness of soybean rust resistance genes present in the 25 soybean accessions against $P$. pachyrhizi in Uganda.

\section{MATERIALS AND METHODS}

The screening trials were done at the National Crops Resources Research Institute (NaCRRI), Namulonge, located in central Uganda at $00^{\circ} 32^{\prime} \mathrm{N}$ and $32^{\circ} 37^{\prime} \mathrm{E}$ at an elevation of 1,150 meters above sea level. The area experiences a bimodal rainfall distribution (average total annual rainfall of $1,100 \mathrm{~mm}$ ) with a general wet and mild dry climate and slightly humid conditions (average $65 \%$ relative humidity). The average minimum temperature is $16.0^{\circ} \mathrm{C}$, while the maximum temperature averages $29.3^{\circ} \mathrm{C}$. Soybean rust epidemics are severe at Namulonge every growing season, making it a suitable location for rust screening experiments (11).

A total of 25 soybean accessions from AVRDC (Table 1) and two local checks (one moderately resistant cultivar, Maksoy $1 \mathrm{~N}$, and one susceptible cultivar, Nam 1) were planted in a randomized complete block design with two replicates. Four of these accessions contained the previously identified specific resistance genes Rppl, $R p p 2$, Rpp3, and Rpp4. Each entry was represented by two rows measuring $5 \mathrm{~m}$ with spacing of $60 \mathrm{~cm}$ between rows and 5 $\mathrm{cm}$ between plants within rows. To promote natural rust development, the susceptible cultivar Nam 1 was sown (at the same time) in and around the test plots. The experiment was conducted for three consecutive growing seasons beginning with the first rains of 2005. During the first rains of 2005, planting was on 21 March 2005 , and for the second rains of 2005 , planting was on 8 September 2005. In the first rains of 2006, planting was on 22 February 2006. Hereafter, these seasons will be referred to as 2005A, 2005B, and 2006A, respectively. Due to limited seed supply for the first trial, experimental plots in the first season consisted of only one row each.

Rust assessment was conducted at growth stage R2 (full bloom), at R4 (full pod formation), and at R6 (full seed formation) (6). Rust was assessed as each line reached a particular growth stage to guard against variation in rust susceptibility due 
to differences in crop growth stages. Rust assessment was made from each plot using a modified 0 to 9 scale adapted from Kawuki et al. (12), where $0=$ no visible disease symptoms, 1.0, 2.0, 3.0, 4.0, 5.0, $6.0,7.0$, and 8.0 indicate 10 to $80 \%$ disease severity, and $9=90 \%$ disease severity plus defoliation based on number and distribution of rust spots on leaves. Days to also recorded to assess the maturity period of these accessions as rust development tends to parallel crop development (18).

Disease and growth data from the trials were analyzed separately for each season. Differences in rust scores among test materials were compared by analysis of variance (ANOVA) with Genstat, 9th ed. (Lawes Agricultural Trust, Rothamsted, UK). Rust scores were normalized by angular transformation before they were subjected to ANOVA (25). Accessions that showed lower rust scores than the resistant local check Maksoy $1 \mathrm{~N}$ were considered to have a greater resistance potential against soybean rust isolate(s) in Namulonge compared to the commercial cultivars in Uganda.

\section{RESULTS}

Rust severities on soybean accessions at various stages. Many of the 25 test accessions were consistently resistant to soybean rust at Namulonge (Table 2). Throughout the three seasons, no soybean rust lesions were observed on the test acflowering and days to maturity (R8) were

cessions at R2. The highly susceptible local check Nam 1 also did not show rust symptoms during this growth stage. During 2005A, at full pod formation (R4), some of the test accessions showed rust lesions. Differences in mean rust scores among accessions were highly significant $(P<0.001)$. Rust lesions were observed on accessions GC 84058-18-4, GC 84051-32$1, \mathrm{G} 7955$, G 10428, G 1882, and on the local checks Maksoy $1 \mathrm{~N}$ and Nam 1. The susceptible local check Nam 1 showed the highest rust score, averaging 6.8. At R6, soybean rust was observed only on accessions that showed rust symptoms at growth stage R4. Significant differences $(P<$ 0.001 ) in rust severity were observed among the accessions. Rust severity increased on accession GC 84051-32-1 and on Maksoy $1 \mathrm{~N}$ and Nam 1, but decreased on the other accessions that were affected at R4. Highest rust scores were recorded on Nam 1, GC 84051-32-1, and Maksoy $1 \mathrm{~N}$.

During 2005B, at R4, rust was observed in some of the accessions including GC 00138-29, GC 84051-32-1, G 10428, SRED-14A, and on the local checks Maksoy $1 \mathrm{~N}$ and Nam 1. The susceptible cultivar Nam 1 had the highest rust score. The other accessions had no symptoms of soybean rust. Mean rust scores varied significantly $(P<0.001)$ among test accessions during this growth stage. At R6, the test accessions again showed highly significant differences $(P<0.001)$ in their reaction to

Table 1. Pedigree information for soybean accessions evaluated for resistance to soybean rust in Uganda

\begin{tabular}{|c|c|c|c|}
\hline No. & Accession & Pedigree & Remarks \\
\hline 1 & GC 00138-29 & $(\mathrm{CH} \# 1 \times$ Anoka $) \times($ Clark $63 \times 64-4)$ & \\
\hline 2 & GC 60020-8-7-7-18 & PI $194647 \times$ TN \#3 & \\
\hline 3 & GC 84051-32-1 & TN \#4 × (Shih Shih $\times$ SRF 400 $)$ & \\
\hline 4 & GC 84058-18-4 & PI $797112613 \times($ PI $79712613 \times$ SJ \#4 $)$ & \\
\hline 5 & GC 85037-2-3-5-1 & Ankur $\times$ PI 230970 & \\
\hline 6 & SS 86045-23-2 & Suwon $132 \times$ Milyang 18 & \\
\hline 7 & GC 87012-10-B-5 & $($ SRF $400 \times$ Tzuzunoko $) \times \mathrm{KS} \# 1$ & \\
\hline 8 & GC 87016-11-B-2 & KS \#1 × Mainland China & \\
\hline 9 & GC 87021-13-B-2 & KS \#1 × 269 & \\
\hline 10 & GC 87021-26-B-1 & KS \#1 × 269 & \\
\hline 11 & SRE-B-15C & Akiyoshi × PI 68728 & \\
\hline 12 & SRE-D-11B & Sanga $\times$ Akiyoshi & \\
\hline 13 & SRE-D-11C & Sanga $\times$ Akiyoshi & \\
\hline 14 & SRE-D-14A & Sanga $\times$ Akiyoshi & \\
\hline 15 & SRE-D-14B & Sanga $\times$ Akiyoshi & \\
\hline 16 & G 8587 & PI 230971 & \\
\hline 17 & G 57 & $\mathrm{TN} 4$ & \\
\hline 18 & G 58 & PI 200492 & $\begin{array}{l}\text { Rppl resistance gene } \\
\text { present }\end{array}$ \\
\hline 19 & G 7955 & Ankur & $\begin{array}{l}\text { Rpp3 resistance gene } \\
\text { present }\end{array}$ \\
\hline 20 & G 10428 & PI 459025 & $\begin{array}{l}\text { Rpp4 resistance gene } \\
\text { present }\end{array}$ \\
\hline 21 & G 8586 & PI 230970 & $\begin{array}{l}\text { Rpp2 resistance gene } \\
\text { present }\end{array}$ \\
\hline 22 & G 2043 & KS 3 & \\
\hline 23 & G 33 & TN 3 & \\
\hline 24 & G 8527 & PI 200490 & \\
\hline 25 & G 1882 & PI 200491 & \\
\hline 26 & Maksoy $1 \mathrm{~N}$ & $\mathrm{TG} \times 1213-1 \mathrm{D} \times \mathrm{TG} \times 1445-3 \mathrm{E}$ & $\begin{array}{l}\text { Moderately resistant } \\
\text { local check }\end{array}$ \\
\hline 27 & Nam 1 & Hales $\times$ P1307-861 & Susceptible local check \\
\hline
\end{tabular}

soybean rust during the second rains of 2005. Rust was observed on accessions $G$ 1882, G 2043, G 58, GC 00138-29, GC 84051-32-1, and GC 87012-10-13-5. The local checks Maksoy $1 \mathrm{~N}$ and Nam 1 also had rust lesions, with Nam 1 having the highest lesion density.

During the first rains of 2006, a number of accessions showed rust lesions at $\mathrm{R} 4$. These included GC 84051-32-1, G 1882, G 2043, G 7955, GC 85037-2-3-5-1, GC 87021-26-B-1, and the local checks Nam 1 and Maksoy 1N. Accessions differed significantly in rust severity at R4 and at R6. At R6, rust was observed only on accessions G10428, G 57, G 7955, GC 84051$32-1$, and on the local checks Nam 1 and Maksoy $1 \mathrm{~N}$.

Across seasons, accessions G 33, G 8527, G8586, G 8587, GC 60020-8-7-718, GC 87016-11-B-2, GC 87021-26-B-1, SRE-D-14A, SRE-D-14B, and SS 8604523-2 showed no rust infection at R6. Nam 1 had the highest mean rust score at R6 across seasons. Maksoy $1 \mathrm{~N}$, a moderately resistant local check, had a higher mean rust severity than all test accessions except GC 84051-32-1. Rust was more severe in the trial conducted during the first rains of 2006 compared to the previous two seasons.

Growth and maturity of test accessions. Growth parameters for test accessions differed significantly $(P<0.05)$ among accessions (Table 3 ). All test accessions reached physiological maturity earlier than the local checks. The earliest accession was G 58, which reached physiological maturity 74 days after planting.

\section{DISCUSSION}

The tests showed high resistance among the AVRDC accessions to soybean rust isolates at Namulonge. Some of the accessions were susceptible to rust, producing mostly a tan lesion phenotype on the leaves. The test materials included four accessions with previously described specific rust resistance genes, Rppl, Rpp2, $R p p 3$, and Rpp4. Among these four accessions, only accession G 8586 showed no rust symptoms during the three seasons, suggesting that the Rpp 2 gene in this accession confers resistance to isolates of soybean rust in Uganda. Three races of soybean rust were reported in Uganda (15), implying that before any of these resistance genes are deployed against rust in Uganda, they should be screened against all races of $P$. pachyrhizi present in the country.

The results also agree with previous reports which indicated that specific resistance to $P$. pachyrhizi can be overcome by some isolates of the pathogen $(10,24)$. Three of the four resistance genes present in some of the test accessions (G 58, G 7955, G 10428, and G 8586) succumbed to $P$. pachyrhizi in Namulonge. This compli- 
cates worldwide host plant resistance breeding efforts because any single resistance gene deployed against the pathogen can easily break down in the presence of pathogen races with multiple virulence factors against genes for resistance (7).

Although the resistance genes contained in four of the accessions tested are specific, they could be of use in improving resistance in the already released moderately resistant cultivars such as Namsoy $4 \mathrm{M}$ and Maksoy $1 \mathrm{~N}$ and in incorporating resistance into popular susceptible cultivars such as Nam II through gene pyramiding. Soybean rust is a worldwide concern and has afflicted soybean in several countries in Africa, including Zimbabwe, Nigeria, and South Africa (16,17). Germplasm screened under African conditions needs to be shared. $P$. pachyrhizi is a recent introduction into the African continent, and there may still be few races of the pathogen in the continent. Soybean rust resistance identified in Uganda will likely be of use in many countries in Africa.

The study also showed that rust became more severe in later maturing accessions than in early maturing accessions, with the latter showing very low rust severities. These results concur with findings of others $(4,12,18)$. These findings also suggest that early maturing accessions tend to es-
Table 3. Flowering and maturity period of germplasm screened at Namulonge

\begin{tabular}{|c|c|c|c|}
\hline No. & Accession & Days to flowering & $\begin{array}{l}\text { Days to physiological } \\
\text { maturity }\end{array}$ \\
\hline 1 & GC 00138-29 & 44 & 90 \\
\hline 2 & GC 60020-8-7-7-18 & 35 & 82 \\
\hline 3 & GC 84051-32-1 & 35 & 88 \\
\hline 4 & GC $84058-18-4$ & 34 & 87 \\
\hline 5 & GC 85037-2-3-5-1 & 39 & 86 \\
\hline 6 & SS 86045-23-2 & 34 & 82 \\
\hline 7 & GC 87012-10-B-5 & 38 & 85 \\
\hline 8 & GC 87016-11-B-2 & 32 & 86 \\
\hline 9 & GC 87021-13-B-2 & 31 & 86 \\
\hline 10 & GC 87021-26-B-1 & 31 & 89 \\
\hline 11 & SRE-B-15C & 33 & 82 \\
\hline 12 & SRE-D-11B & 33 & 82 \\
\hline 13 & SRE-D-11C & 33 & 81 \\
\hline 14 & SRE-D-14A & 29 & 81 \\
\hline 15 & SRE-D-14B & 34 & 88 \\
\hline 16 & G 8587 & 33 & 89 \\
\hline 17 & G 57 & 34 & 82 \\
\hline 18 & G 58 & 31 & 74 \\
\hline 19 & G 7955 & 45 & 86 \\
\hline 20 & G 10428 & 33 & 88 \\
\hline 21 & G 8586 & 44 & 84 \\
\hline 22 & G 2043 & 39 & 87 \\
\hline 23 & G 33 & 31 & 82 \\
\hline 24 & G 8527 & 33 & 82 \\
\hline 25 & G 1882 & 34 & 82 \\
\hline 26 & Maksoy 1N & 46 & 94 \\
\hline \multirow[t]{4}{*}{27} & Nam 1 & 47 & 102 \\
\hline & $\mathrm{LSD}_{5 \%}$ & 1.7 & 2.4 \\
\hline & $\mathrm{CV} \%$ & 2.3 & 1.3 \\
\hline & $F$ prob. & $<0.001$ & $<0.001$ \\
\hline
\end{tabular}

Table 2. Rust reaction of 27 soybean accessions under natural infection by Phakopsora pachyrhizi at Namulonge, Uganda during growing seasons beginning with first rains 2005 (2005A), second rains 2005 (2005B), and first rains 2006 (2006A)

\begin{tabular}{|c|c|c|c|c|c|c|c|c|c|}
\hline & \multirow[b]{3}{*}{ Accession } & \multicolumn{8}{|c|}{ Mean rust severity ( 0 to 9 scale) over three seasons } \\
\hline & & \multicolumn{2}{|c|}{ 2005A } & \multicolumn{2}{|c|}{ 2005B } & \multicolumn{2}{|c|}{ 2006A } & \multicolumn{2}{|c|}{ Mean } \\
\hline & & $\mathbf{R 4}^{\mathbf{a}}$ & $\mathbf{R 6}^{\mathbf{a}}$ & $\mathbf{R 4}$ & R6 & $\mathbf{R 4}$ & R6 & $\mathbf{R 4}$ & R6 \\
\hline 1 & GC 00138-29 & 0.0 & 0.0 & 0.5 & 1.3 & 0.0 & 0.0 & 0.2 & 0.4 \\
\hline 2 & GC 60020-8-7-7-18 & 0.0 & 0.0 & 0.0 & 0.0 & 0.0 & 0.0 & 0.0 & 0.0 \\
\hline 3 & GC 84051-32-1 & 3.5 & 3.8 & 0.8 & 2.5 & 3.3 & 5.3 & 2.6 & 3.9 \\
\hline 4 & GC 84058-18-4 & 1.0 & 0.6 & 0.0 & 0.0 & 0.0 & 0.0 & 0.4 & 0.2 \\
\hline 5 & GC 85037-2-3-5-1 & 0.0 & 0.0 & 0.0 & 0.0 & 1.3 & 0.0 & 0.4 & 0.0 \\
\hline 6 & SS 86045-23-2 & 0.0 & 0.0 & 0.0 & 0.0 & 0.0 & 0.0 & 0.0 & 0.0 \\
\hline 7 & GC 87012-10-B-5 & 0.0 & 0.0 & 0.0 & 1.8 & 0.0 & 0.0 & 0.0 & 0.6 \\
\hline 8 & GC 87016-11-B-2 & 0.0 & 0.0 & 0.0 & 0.0 & 0.0 & 0.0 & 0.0 & 0.0 \\
\hline 9 & GC 87021-13-B-2 & 0.0 & 0.0 & 0.0 & 0.0 & 0.0 & 0.0 & 0.0 & 0.0 \\
\hline 10 & GC 87021-26-B-1 & 0.0 & 0.0 & 0.0 & 0.0 & 1.5 & 0.0 & 0.5 & 0.0 \\
\hline 11 & SRE-B-15C & 0.0 & 0.0 & 0.0 & 0.0 & 0.0 & 0.0 & 0.0 & 0.0 \\
\hline 12 & SRE-D-11B & 0.0 & 0.0 & 0.0 & 0.0 & 0.0 & 0.0 & 0.0 & 0.0 \\
\hline 13 & SRE-D-11C & 0.0 & 0.0 & 0.0 & 0.0 & 0.0 & 0.0 & 0.0 & 0.0 \\
\hline 14 & SRE-D-14A & 0.0 & 0.0 & 0.3 & 0.0 & 0.0 & 0.0 & 0.1 & 0.0 \\
\hline 15 & SRE-D-14B & 0.0 & 0.0 & 0.0 & 0.0 & 0.0 & 0.0 & 0.0 & 0.0 \\
\hline 16 & G 8587 & 0.0 & 0.0 & 0.0 & 0.0 & 0.0 & 0.0 & 0.0 & 0.0 \\
\hline 17 & G 57 & 0.0 & 0.0 & 0.0 & 0.0 & 0.0 & 3.3 & 0.0 & 1.1 \\
\hline 18 & G 58 & 0.0 & 0.0 & 0.0 & 1.3 & 0.0 & 0.0 & 0.0 & 0.4 \\
\hline 19 & G 7955 & 1.0 & 0.6 & 0.0 & 0.0 & 0.5 & 3.0 & 0.6 & 1.2 \\
\hline 20 & G 10428 & 1.5 & 0.8 & 1.8 & 0.0 & 0.0 & 3.3 & 1.1 & 1.4 \\
\hline 21 & G 8586 & 0.0 & 0.0 & 0.0 & 0.0 & 0.0 & 0.0 & 0.0 & 0.0 \\
\hline 22 & G 2043 & 0.0 & 0.0 & 0.0 & 2.3 & 1.5 & 0.0 & 0.5 & 0.8 \\
\hline 23 & $\mathrm{G} 33^{\mathrm{b}}$ & 0.0 & 0.0 & & & & & 0.0 & 0.0 \\
\hline 24 & G 8527 & 0.0 & 0.0 & 0.0 & 0.0 & 0.0 & 0.0 & 0.0 & 0.0 \\
\hline 25 & G 1882 & 2.3 & 1.5 & 0.0 & 1.5 & 0.5 & 0.0 & 0.9 & 1.0 \\
\hline 26 & Maksoy 1N & 2.8 & 3.5 & 2.0 & 3.3 & 3.3 & 4.3 & 2.7 & 3.7 \\
\hline \multirow[t]{3}{*}{27} & Nam 1 & 6.8 & 7.0 & 4.3 & 7.0 & 4.5 & 5.8 & 5.2 & 6.6 \\
\hline & Mean & 0.7 & 0.7 & 0.4 & 0.8 & 0.6 & 1.0 & 0.6 & 0.8 \\
\hline & $F$ prob. $^{\mathrm{c}}$ & $<0.001$ & 0.001 & $<0.001$ & $<0.001$ & $<0.001$ & $<0.001$ & $<0.001$ & $<0.001$ \\
\hline
\end{tabular}

${ }^{\text {a }}$ Growth stages $\mathrm{R} 4=$ full pod formation, and R6 = full seed formation.

${ }^{\mathrm{b}}$ No seed recovered from 2005A.

c ANOVA conducted on angular transformed values. 
cape severe infection. Care should be taken in using such accessions as sources of resistance genes. Another notable finding was that some accessions showed rust pustules at R4 but not at R6. This could be due to a recovery mechanism in these accessions, but further investigations are necessary to ascertain the exact basis for such findings.

This study has shown that the exotic germplasm from AVRDC is more resistant to soybean rust in Uganda than the local cultivars. Nonetheless, hybridizations followed by backcrossing programs are necessary to introgress resistance genes into the local cultivars, as most of the exotic accessions were not adapted to Ugandan conditions.

\section{ACKNOWLEDGMENTS}

We acknowledge the Regional Universities Forum for Capacity Building in Agriculture (RUFORUM) for funding the study.

\section{LITERATURE CITED}

1. Anonymous. 2006. Soybean Rust Management in the Mid-Atlantic Region. South Carolina Department of Agriculture, Columbia, SC.

2. AVRDC. 1992. Annotated bibliography of soybean rust (Phakopsora pachyrhizi Sydow). Library Bibliography series 4-1, Tropical Vegetable Information Service, Asian Vegetable Research and Development Center.

3. Bromfield, K. R. 1984. Soybean rust. Monogr. no. 11. American Phytopathological Society, St. Paul, MN.

4. do Vale, F. X. R., Chaves, G. M., and Zambolim, L. 1985. Effect of planting time on the incidence of soybean rust. Soybean Rust Newsl. 7:4-6.

5. Dorrance, A. E., Draper, M. A., and Hershman, D. E., eds. 2007. Using foliar fungicides to manage soybean rust. Land-Grant Universities Cooperating NCERA-208 and OMAF.

6. Fehr, W. R., and Caviness, C. E. 1977. Stages of soybean development. Cooperative Extension Service, Agricultural and Home Economics Experiment Station, Spec. Rep. 80. Iowa State University, Ames.

7. Hartman, G. L., Miles, M. R., and Frederick, R. D. 2005. Breeding for resistance to soybean rust. Plant Dis. 89:664-666.

8. Hartman, G. L., Sinclair, J. B., and Rope, J. C. 1999. Compendium of Soybean Diseases, 4th ed. American Phytopathological Society, St. Paul, MN.

9. Hartwig, E. E. 1986. Identification of a fourth major gene conferring resistance to soybean rust. Crop Sci. 26:1135-1136.

10. Hartwig, E. E., and Bromfield, K. R. 1983. Relationships among three genes conferring specific resistance to rust in soybeans. Crop Sci. 23:237-239.

11. Kawuki, R. 2002. Soybean germplasm reaction to rust in Uganda, associated yield loss and rust control using fungicides. MSc. thesis. Makerere University, Kampala.

12. Kawuki, R., Adipala, E., and Tukamuhabwa, P. 2003. Yield Loss Associated with Soya bean Rust (Phakopsora pachyrhizi Syd.) in Uganda. J. Phytopathol. 151:7-12.

13. Kawuki, R., Tukamuhabwa, P., and Adipala, E. 2004. Soybean rust severity, rate of rust development, and tolerance as influenced by maturity period and season. Crop Prot. 23:447-455.

14. Kiryowa, M., Tukamuhabwa, P., and Adipala, E. 2005. Inheritance of resistance to soybean rust. Afr. Crop Sci. Conf. Proc. 7:257-260.

15. Lamo, J. 2004. Occurrence, characterisation and development of inoculation techniques for Phakopsora pachyrhzi in Uganda. MSc. thesis. Makerere University, Kampala.

16. Levy, C. 2003. Measures to control soybean rust in Southern Africa and an initial investigation of the meteorological factors that favor its development. (Abstr.) Phytopathology 93:S103.

17. Levy, C. 2005. Epidemiology and chemical control of soybean rust in southern Africa. Plant Dis. 89:669-674.

18. Manandhar, J. B., and Joshi, S. 1983. Soybean Rust in Nepal. (Abstr.) Phytopathology 73:843.

19. Patil, P. V., and Anahosur, K. H. 1998. Control of soybean rust by fungicides. Ind. Phytopathol. 51:265-268.

20. Pivonia, S., and Yang, X. B. 2004. Assessment of the potential year-round establishment of soybean rust throughout the world. Plant Dis. 88:523-529.

21. Pivonia, S., and Yang, X. B. 2006. Relating epidemic progress from a general disease model to seasonal appearance time of rusts in the United States: Implications for soybean rust. Phytopathology 96:400-407.

22. Rossi, R. L. 2003. First report of Phakopsora pachyrhizi, the causal organism of soybean rust in the province of Misiones, Argentina Plant Dis. 87:102.

23. Schneider, R. W., Hollier, C. A., Whitam, H. K., Palm, M. E., McKemy, J. M., Hernandez, J. R., Levy, L., and DeVries-Paterson, R. 2005. First report of soybean rust caused by Phakopsora pachyrhizi in the continental United States. Plant Dis. 89:774.

24. Sinclair, J. B., and Hartman, G. L., eds. 1996. Proceedings of Soybean Rust Workshop, 1995. National Soybean Research Laboratory Publ. 1. College of Agricultural, Consumer and Environmental Sciences, University of Illinois, Urbana-Champaign.

25. Sokal, R. R., and Rohlf, F. J. 1995. Biometry, the Principles and Practice of Statistics in Biological Research. 3rd ed. W. H. Freeman and Company, New York. pp. 419-422.

26. Tukamuhabwa, P., ed. 2006. How to grow soybeans in Uganda, July 2006 edition. Makerere University Kampala.

27. Tukamuhabwa, P., Dashiell, K. E., and AssafoAdjei, B. 2001. Determination of yield loss caused by soybean rust (Phakopsora pachyrhizi Syd.) in four genotypes of soybeans. Afr. Crop Sci. Conf. Proc. 5:423-426.

28. Uganda Seed Project, 2001. Soybean rust disease. A report to the National Agricultural Research Organisation, Entebbe, Uganda. p. 6.

29. Yorinori, J. T., Paiva, W. M., Frederick, R. D. Costamilan, L. M., Bertagnolli, P. F., Hartman, G. E., Godoy, C. V., and Nunes, J., Jr. 2005. Epidemics of soybean rust (Phakopsora pachyrhizi) in Brazil and Paraguay from 2001 to 2003. Plant Dis. 89:675-677. 